\title{
Article \\ 'The Game of the Sea': An Interdisciplinary Educational Board Game on the Marine Environment and Ocean Awareness for Primary and Secondary Students
}

\author{
Elena Arboleya-García 1,*(D) and Laura Miralles ${ }^{2,3}$ (D) \\ 1 Department of Education Sciences, University of Oviedo, 33005 Oviedo, Spain \\ 2 Department of Functional Biology, University of Oviedo, 33006 Oviedo, Spain; 1ml.miralles@gmail.com \\ 3 Department of Environmental Genetics, Ecohydros, 39600 Maliaño, Spain \\ * Correspondence: elenaarboleyagarcia@gmail.com
}

Citation: Arboleya-García, E.;

Miralles, L. 'The Game of the Sea': An Interdisciplinary Educational Board Game on the Marine Environment and Ocean Awareness for Primary and Secondary Students. Educ. Sci. 2022, 12, 57. https://doi.org/ 10.3390/educsci12010057

Academic Editors: José Carlos Piñero Charlo, María Teresa Costado Dios,

Enrique Carmona Medeiro and

Fernando Lloret

Received: 6 December 2021

Accepted: 13 January 2022

Published: 16 January 2022

Publisher's Note: MDPI stays neutral with regard to jurisdictional claims in published maps and institutional affiliations.

Copyright: (C) 2022 by the authors. Licensee MDPI, Basel, Switzerland. This article is an open access article distributed under the terms and conditions of the Creative Commons Attribution (CC BY) license (https:// creativecommons.org/licenses/by/ $4.0 /)$.

\begin{abstract}
Games are a proven tool for learning at all ages and in many contexts. They increase the attractiveness of learning processes through arousing interest and enhancing motivation, and aid with the development of social skills. Educational games provide teachers with different approaches to teaching. 'The Game of the Sea' is an interdisciplinary board game, specifically designed to teach its players about the marine environment, regardless of their age. Through its 68 sections, coloured according to particular topics and organised as a fish shape, players encounter a wide range of questions and activities. Through playing this game, players acquire a broad knowledge of science, the marine environment and its importance, and literature. The game uses an interdisciplinary approach with question cards on a variety of topics (including maths, physics, biology, chemistry, art, etc.). A total of 222 players (111 children, aged 11-15, and 111 adults, aged 18-72) tested the game. These players were enrolled in different formal and non-formal educational contexts and had different educational backgrounds. For a qualitative analysis of game sessions (participant observation), researchers acted as game moderators and, while doing so, made subtle observations of players playing the game. On top of this, the value of the game, as a didactic tool, was evaluated with a test that players took before and after the game. After playing the game, knowledge of the marine environment, increased in both children and adults, with a slightly higher increase in children. Therefore, 'The Game of the Sea' is suitable for teaching all ages about the marine environment. Further, this game can impart to its players the importance of the marine environment and the importance of protecting this environment.
\end{abstract}

Keywords: educational game; game-based learning; board game; learning tool; teaching-learning process; interdisciplinary learning; science learning; marine environment; environmental awareness; skills development

\section{Introduction}

Games are present throughout all stages of life, from childhood and adolescence to adulthood and old age. Moreover, games have been played throughout the existence of human beings. Indeed, playing games is thought to have been essential for the evolution of civilization [1]. Additionally, by being part of social and cultural activities, games can provide important social experiences. Games can be typically described as fun, voluntary, having prescribed settings in time and space and being constrained by rules and procedures (yet being somewhat, unpredictable) [2,3]. Thus, a wide range of social interactions in which people collaborate and/or compete with the aim of achieving determined goals can be considered games [4].

Games can be categorised depending on their purpose: entertainment or education [5]. Educational games have all the characteristics mentioned before, but are specifically designed to achieve learning goals [6,7], and have been proposed as a mean to prevent 
students failing school [7]. These games try to develop player's cognitive and operational abilities (while reinforcing their social development) through teaching them specific concepts, so that they can understand and expand on these [8]. Therefore, these games should be designed to be teaching materials [9], not just to provide entertainment [10] (although they should be enjoyable too [11]).

Nowadays, educational games are implemented for teaching skills, and academic content, in such different fields as health, business, science, the military, etc., at different levels of education and in different educational contexts (formal, non-formal, and informal) [12,13]. Educational games are sometimes digital [14], though certain scholars think that they should be tangible and face-to-face. Further, non-digital games could supply more, and deeper, interactions among peers and, also, easily allow adaptations of game design to include a wider variety of activities to adapt to different learning styles, or maintain the participant's interest [15]. Gamification is another way in which game elements can be used in education. This does not entail a complete game process, but rather employs whichever elements of games (e.g., badges, game dynamics, etc.) best help players to reach specific goals in their education or improve how they behave with others in non-game contexts [16]. Gamification is employed in fostering students' enthusiasm, by, for instance, providing them with immediate feedback during performance and enhancing recognition of their achievements [17] inside learning contexts.

Both educational games and gamification can be referred to as game-based learning (GBL). GBL uses a learner-centred approach to help learners obtain usable knowledge while developing a wide range of skills [18]. GBL has many benefits. Games have been linked to academic achievement, regardless of the educational stage of the participants [19]. Educational experiences based on GBL allow students to be active participants, rather than passive observers, as they learn through participating in game activities (i.e., problemsolving, making decisions, and reacting to the results of these activities) [20]. GBL gives learners the chance to take risks without real consequences, and reduces their feelings of being exposed as having lower levels of knowledge [21]. Indeed, as games allow players to repeat failed tasks and correct previous mistakes, negative experiences can be transformed into a final success that promotes positive attitudes towards learning through playing [22]. GBL challenges players in a positive way [23], promotes social interactions, fosters attention and concentration, facilitates the construction of long-term memories (through providing continuous and personalized feedback, which also helps tackle misconceptions), and develops emotional skills [24] better than traditional teaching methods [25]. Neuroscience demonstrates further benefits of using GBL. Not only does GBL activate the reward system in the brain, it is also more likely to stimulate retention and engage players toward more effective cognition compared to more traditional methods of education [26,27]. GBL encourages creativity in teaching complex subjects (e.g., sciences) [28]. Games used to teach science subjects can be specifically designed for students' needs so that they can acquire complex knowledge while having fun (thus distracting them from the fact that they are learning [29]).

Despite its many benefits, GBL has some drawbacks. The most common of these is perhaps that games take time and effort, not only to play but also to design, test and implement [18]. This can lead to difficulties in time management and, also, players feeling frustrated if they do not complete the game. Additionally, some players may not take the game seriously. Not only these players may fail to attain the knowledge that they should from the game, teachers might find it hard to determine where they have gaps in their knowledge [21]. An already developed game, aligned with the contents of the curricula used in formal education, or the formative program used in informal education, would remove the need for teachers to design and test their own games. Such a game could enable students to reach the same educational goals in less time than traditional methodologies and materials [30].

Board games have been the most popular kind of non-digital games for centuries and, in all age groups, are still the kind most played by people [31]. Board games are also tradi- 
tionally used, in GBL, for developing academic knowledge and cognitive skills, and have a number of advantages that aid with this. They can address different learning styles [20,32], contents and procedures to be adapted for personalised sessions [33]. They allow players to learn by doing, foster hands-on skills, and promote self-confidence and self-learning [34,35]. They can have clear rules that make it easy to understand, initiate, and sustain game play at an adequate rhythm [36]. They use a combination of tangible materials, turn-taking modes, and face to face interactions among peers or teams [37]. They create a non-threatening environment that supports mutual learning [29] since they provide opportunity for players to receive feedback or clarification, have discussions, and reflect on the game [38], which benefits both peers and game moderators [39]. They involve competition, which can be highly positive, if this motivates players to cooperate with each other and do their best in the game [40]. Nevertheless, success in educational games is based more on aptitude and knowledge than on competitiveness. The above suggests board games to be a powerful educational tool for all ages, across educational contexts [12], in alignment with the longlife learning concept, which implies learning with, and from, other people [20]. Evidence for the success of board games as educational tools include their already frequent use in different educational contexts and in teaching many different subjects. When introduced in university contexts, board games were not considered a childish activity or a waste of time [41]. Such games have yielded excellent results at Undergraduate and Master's levels [42,43]. At the other end of the academic spectrum, playing games is the most frequent learning activity in Elementary and Primary Education [28]. Among the many different subjects taught with board games [44] are architecture [45], astronomy [18,46], biochemistry [47], chemistry [35], ecology [48], electronical engineering [49], environmental sciences [50], healthcare sciences [29,51,52], palaeontology [53], pharmacy [54], chemical engineering [55], and engineering [56].

In this sense, board games could help people better understand how the marine environment and humanity influence each other. This is ocean literacy, conceptualized as 'an understanding of the ocean's influence on citizens and citizens' influence on the ocean' [57]. Accordingly, board games could be used as an effective communication tool to generate environmental awareness [58]. This is important as, with this understanding, people can better communicate information on the marine environment and make conscientious decisions regarding this $[59,60]$. Through playing board games, players could learn about specific concepts such as sustainability problems that marine ecosystems currently face, as well as how to restore and protect the marine environment. Such education should be present for all ages [61], although children are most likely to change their behaviours in response to it [62]. A better understanding of ecosystems comes from scientific knowledge but arts (in its broader conceptualization as paintings, films, documentaries, etc.) also have the capability to engage people and foster environmental awareness [63].

Here, we present 'The Game of the Sea', a game, suitable for any educational context, regardless of the players age, which focuses on specific curricula contents that can lay the foundation for a deeper understanding of the marine environment. 'The Game of the Sea' has an interdisciplinary approach, which integrates information on the marine environment from different disciplines. This differs from a multidisciplinary approach as, while the latter also involves different disciplines, each discipline provides a specific perspective, typically resulting in poor, or null, connections between them [64].

Creating an attractive educational game, which can be successfully used for teaching science, and raising awareness on environmental issues, while holding the players' attention for a long-time, can be difficult [25]. Nevertheless, the development of such games should be encouraged, as they promote the development of important skills. These skills include critical thinking (if the game requires scientific reasoning, decision making and problem solving), collaboration (if players need to work together), creativity (if players need to think outside the box), and communication (if players need to share ideas) $[6,65,66]$. On top of this, educational games strengthen students' autonomy, self-confidence, and self-esteem. Thus, 'The Game of the Sea' was conceived to teach and learn about marine environment, 
based on both popular quizzes and board games with a background of sciences such as physics, biology, mathematics, geology, chemistry, or literature.

The 'Game of the Sea' was specifically designed for rising citizen awareness about marine conservation while enjoying and learning. The learning goals of this game are: (1) To enable students to achieve learning objectives (based on the official curricula of Spanish Compulsory High School Education) in terms of learning about the marine environment. (2) To foster collaborative learning, regardless of age or educational background. (3) To raise awareness about critical situations regarding our marine environment, and the need to preserve this environment. The learning objectives of the game are for players: (a) To recognise organisms from marine ecosystems. (b) To identify invasive marine species and their environmental consequences. (c) To relate geological concepts to marine phenomena. (d) To apply laws of mathematics, physics, and chemistry to understanding the marine environment. (e) To understand how information about the marine environment that they learnt in schools applies to their daily life. (f) To analyse literary works related to the marine environment. (g) To discuss and compare information about each topic involved in the game. (h) To produce a wide variety of creative works focused on the marine environment. We designed the game based on three main questions that need to be taken into account in educational game design [67]: (1) What are the learning objectives. (2) What materials are needed to reach the learning objectives (i.e., what are the learning contents). (3) How can students learn while playing the game (i.e., what is the learning methodology). To answer to these questions, we trialled the game in different places in Asturias, a coastal region in Northern Spain. People from formal, non-formal, and informal educational contexts, and between the ages of 7 and 72 , took part in these trial game play sessions with satisfactory knowledge acquirement results.

\section{Materials and Methods}

\subsection{Game Materials}

'The Game of the Sea' is a dice-based game inspired by the popular 'Trivia' game model (Figure 1). Playing materials have been specifically designed by authors for this educational purpose. Learning objectives, learning contents, and learning methodology were previously defined and taking into account before designing the game. Learning objectives were enumerated in a list and materials were designed accordingly to reach all of them. Once the goals were defined, learning contents and learning methodology were designed to meet the games learning goals and objectives (listed earlier). The game included elements of physics, biology, mathematics, geology, chemistry, and literature in an interdisciplinary approach, in which different disciplines are used together to improve overall understanding. The game was registered in Spain under the copyright reference 05/2017/329.

'The Game of the Sea' consists of a board on which is printed a fish shape (another marine related shape-an octopus, star fish, or a whale, for instance-could be used instead), divided into 68 sections coloured blue, yellow, red, or green. There is also one additional section where all the individual team pieces are placed, at the start of the game. Inside the shape are four rectangles (blue, yellow, red, and green) on which cards of matching colour are placed. 


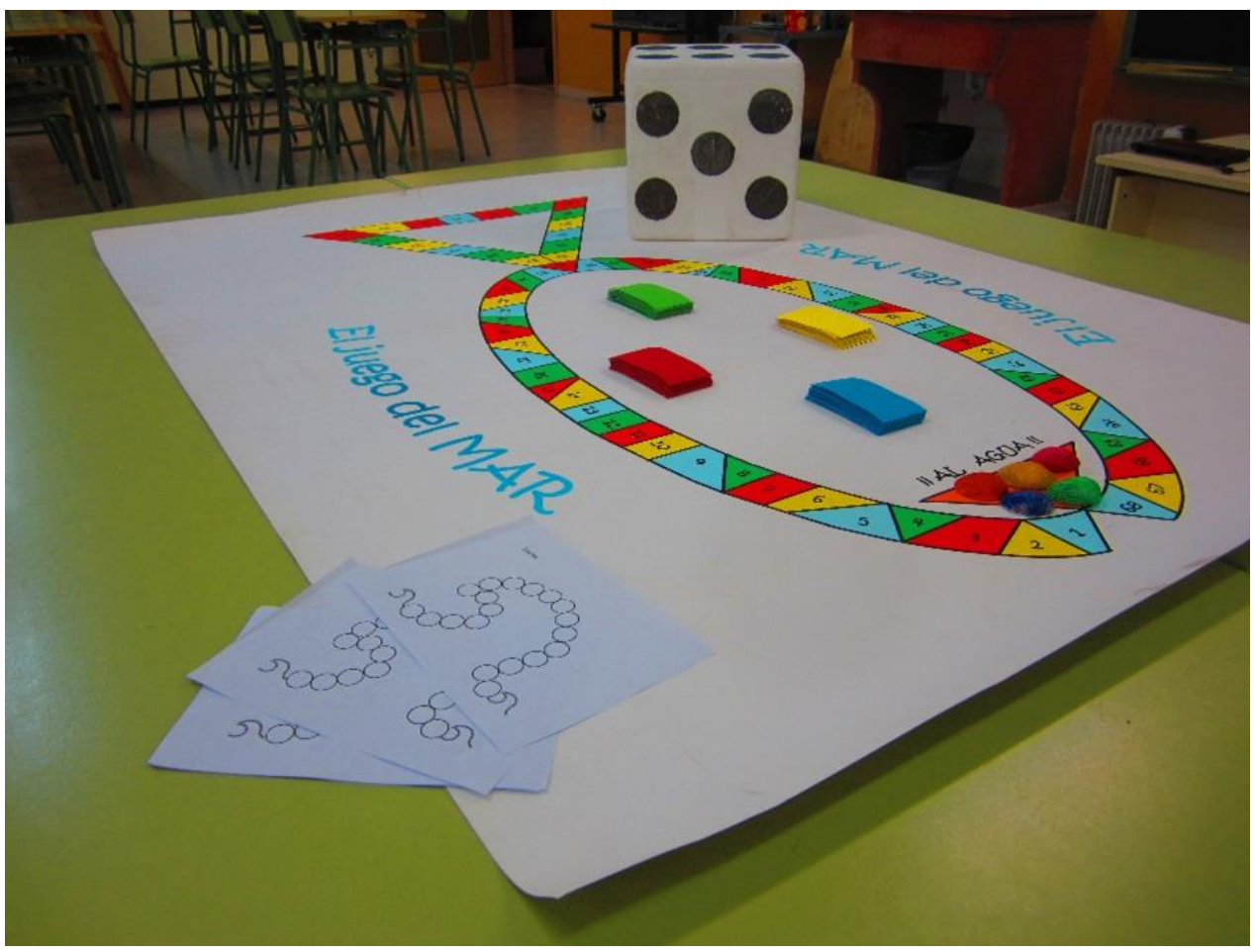

Figure 1. Playing materials needed to play 'The Game of the Sea': game board, question cards, dice, player's pieces, scoreboards, and circular stickers.

The cards $(n=80)$ are the learning content of this game and contain a variety of simple activities (e.g., multiple-choice questions, problem solving, filling gaps, comparing photographs, etc.) to maintain the players' interest. These cards were carefully designed to be easily readable and comprehensible, and are coloured based on which part of the European educational syllabuses they aimed to teach about:

- Blue: marine environments, water properties, marine invasive species and the threats they present to marine ecosystems.

- Red: elements from popular Spanish culture and literature, such as poems or tongue twisters, as well as artistic creations (all illustrating the relationship between the arts and the marine environment).

- Green: simple experiments and questions on Biology, Geology, Physics, Chemistry and Mathematics; all linked to the marine environment.

- Yellow: cards of this colour did not refer to the educational syllabus, but rather contained light-hearted activities designed to entertain and relax participants.

Additionally, required to play the game are one dice, game pieces, scoreboards, and circular stickers. Game pieces (e.g., seashells, painted in different colours) are used to represent each player or team moving along the board. Scoreboards are in the shape of a wave formed by several circles. Each time a player scores a point they place a sticker in one of the circles of the wave score board.

\subsection{Rules of Play}

The most dynamic option to play 'The Game of the Sea' is in small groups of two to six players, although the game can be also played individually. The first step is to make teams and get a scoreboard and a game piece per team. Each team puts their piece in the initial square. Then, a player from each team rolls the die. The team with the highest number starts playing by moving their piece as many squares as the number on the die indicates.

Next, one member of the team takes a card of the same colour as the colour of the section their piece lands on. The text on the card should be read aloud, clearly, ensuring the rest of the players (even those from other teams), can understand what is read. In 
this way, if the first team does not complete the activity on the card, other teams have the opportunity to do so and get extra points.

Players have five seconds to answer the question or complete the activity on the card. This ensures the game has good rhythm and helps players follow it easily. If extra time is allowed (for another kind of activities, such us scientific experiments), this is indicated on the card. Regarding those cards that contain scientific experiments, the team should first choose an answer and then carry out the experiment to test this. When a team scores, they get a sticker to complete the wave printed in their scoreboard. The game will finish when a team succeeds in completing the wave with all stickers.

As a recommendation, the game should have a moderator. This person can not only explain and enforce rules and game timing [58], but also, as they know the solutions to the cards, provide deeper explanations of these and help players come up with solution. However, the moderator ought to allow participants to first try to explain card contents, and solutions, to their team players, before explaining these themselves. Moderators should also encourage collaborative learning and aim to ensure that there is more communication among teams than between the teams and themselves.

\subsection{Players}

Pilot studies of how the game could function (duration, audience, etc.) were carried out in two different samples: children from 7 to 15 years old during the educational event on marine environment 'Aula del Mar' and in 'El Pez Escorpión' surf school (both in Salinas, Asturias, Spain), and adults from 24 to 50 years old from the International Workshop ALERTOOLS (Avilés, Asturias, Spain). The principal aim of these pilot studies was to identify possible limitations regarding materials, contents, or procedures [68]. Furthermore, from the pilot study we identified six questions which were used to develop a test to assess the success of our game (see '2.6. Game assessment'). Game sessions in the pilot study and in later assessment lasted between one to one and a half hours, approximately (there was no set time restriction).

After the game was refined based on the pilot studies, two further samples were selected to assess the game as a didactic tool. We had one children sample and one adult sample, thus we could check the appropriateness of the game for different age groups. These samples were selected intentionally [69], according to the interest of instructors from each educational context that the samples came from. One of the samples 'children' (Table 1) was formed by 111 students, between 11-15 years old, from two high schools from Asturias (Spain): IES Escultor Juan de Villanueva (Pola de Siero-Asturias) and IES Salinas (Salinas-Asturias). The other sample 'adults' (Table 2) was composed of 111 people between 18 and 72 years old. These were either university students from Elementary Teaching Degree, High School Teaching Master of the University of Oviedo, who came from different locations, or adults who had enrolled in Lifelong Learning education programmes at the University of Oviedo (Evolution Club) who were from Oviedo and Avilés (Asturias). All participants $(n=222)$ had different educational backgrounds, thus enabling us to assess the effectiveness of this didactic tool on people with a variety of different academic levels and experiences. We tested the game six times in children and six times in adults, therefore we collected data from 12 game sessions in total.

Table 1. 'Children'. Sample formed by people between 11-15 years old.

\begin{tabular}{cccc}
\hline & $\begin{array}{c}\text { IES Escultor } \\
\text { Juan de Villanueva }\end{array}$ & IES Salinas & N (\%) \\
\hline Female & 44 & 19 & $63(56.8)$ \\
Male & 34 & 14 & $48(43.2)$ \\
\hline
\end{tabular}


Table 2. 'Adults'. Sample formed by people older than 18 years.

\begin{tabular}{ccccc}
\hline & $\begin{array}{c}\text { Elementary } \\
\text { Teaching Degree }\end{array}$ & $\begin{array}{c}\text { High School } \\
\text { Teaching Master }\end{array}$ & $\begin{array}{c}\text { Evolution } \\
\text { Club }\end{array}$ & N (\%) \\
\hline Female & 20 & 21 & 18 & $59(53.2)$ \\
Male & 10 & 29 & 13 & $52(46.8)$ \\
\hline & & & 111 \\
\hline
\end{tabular}

If the players were children, high school science teachers also took part in the sessions. Although they performed a secondary role during the gameplay sessions, their involvement was highly valuable because they could illustrate to their students how material on the game cards linked to their curricula contents.

\subsection{Ethics Statement}

This study adhered to the European Code of Conduct for Research Integrity. All players were informed that all data would be collected and used only for research, and gave informed consent for this. For children and teenagers under 18, their parents signed a participation permit, and their headmasters and teachers gave us permission to play the game for several sessions that fitted into their high school timetable. Adults from Elementary Teaching Degree, High School Teaching Master and Evolution Club, played the game as volunteers.

\subsection{Qualitative Analysis of the Game}

Participant observation was the qualitative research technique employed in different stages of 'The Game of the Sea' development. In particular, it had a relevant implication in those stages referred to test the game during the pilot study first, and its implementation with the sample selected after. This technique consists of the researchers being part of the observed situation. The researchers had access to the information about how phenomena took place, without interactions, in contrast to external observation processes. In this sense, information collected was more accurate than information collected through more obvious external observations [70-72], in which players may have felt scrutinized, would have been.

Researchers obtained qualitative data on the whole gameplay process of 'The Game of the Sea'. The researchers acting as the moderators collected this data by observing the participants as they played the game. They were subtle about doing so, helping players to relax and act naturally. The moderators noted the different ways that players perceived the questions and instructions on the cards and interacted with their peers to respond to these. By doing so, the moderators could not only determine whether game's contents and methodology enabled players to achieve the learning objectives of the game, but also whether collaborative learning took place. Participant observation provided an insight into the whole gameplay process. Data and information collected were registered through field notes.

The analysis of the whole process was focused on learning objectives, learning contents, and learning methodology. The participant observation technique yields interesting information regarding perception of the contents of the questions, and the own answer given to each question by players. Moreover, participant observation contributes to examine the internal team process to choose a response, and also the explanations, discussions, and reflections generated during the gameplay process.

\subsection{Game Assessment}

Based on our pilot studies, we created a brief test which, in later game play sessions, we gave to players before ('pre-test') and after ('post-test') playing 'The Game of the Sea' to verify if players achieved the learning objectives of the game and to evaluate if this game was an effective didactic tool. 
The test consisted of six questions where the player chose what they thought was the correct answer from multiple options. Players could also indicate if they were unaware of the answer. The six questions related to three topics covered in the game: Biology, Physics, and Literature (Table 3). The test was checked by 10 people, before implementation as a game assessment tool, to ensure clarity and consistency between questions and answers. A time limit of five minutes was given, on both occasions, for the test. Players were not told about the post-test to avoid them attempting to memorise correct answers from the pre-test.

Table 3. Test used to assess the success of the Game of the Sea in teaching our learning objectives.

\begin{tabular}{|c|c|c|}
\hline \multirow{8}{*}{ Biology } & \multirow{4}{*}{$\begin{array}{l}\text { Q1. Invasive alien species, } \\
\text { are harmful to ... }\end{array}$} & A. Society, economy, and ecology. ${ }^{1}$ \\
\hline & & B. Only to ecology. \\
\hline & & C. They are not harmful. \\
\hline & & D. I do not know. \\
\hline & \multirow{4}{*}{$\begin{array}{l}\text { Q2. What kind of animal are } \\
\text { cetaceans? }\end{array}$} & A. Fish. \\
\hline & & B. Mammals. ${ }^{1}$ \\
\hline & & C. Birds. \\
\hline & & D. I do not know. \\
\hline \multirow{8}{*}{ Physics } & \multirow{4}{*}{$\begin{array}{l}\text { Q3. Where does the speed of a } \\
\text { sound go faster? }\end{array}$} & A. In the water. ${ }^{1}$ \\
\hline & & B. In the air. \\
\hline & & $\begin{array}{l}\text { C. The sound speed is the same in both, } \\
\text { water, and air. }\end{array}$ \\
\hline & & D. I do not know. \\
\hline & \multirow{4}{*}{$\begin{array}{l}\text { Q4. If we have two balloons, } \\
\text { one with air and the other one } \\
\text { with some water, and we heat } \\
\text { them, which one will blow } \\
\text { out first? }\end{array}$} & A. The balloon only with air. ${ }^{1}$ \\
\hline & & B. The balloon with some water. \\
\hline & & C. Both will blow out at the same time. \\
\hline & & D. I do not know. \\
\hline \multirow{8}{*}{ Literature } & \multirow{4}{*}{$\begin{array}{l}\text { Q5. The follow poem was } \\
\text { written by José de Espronceda, } \\
\text { what is its title? (We read a } \\
\text { piece of the poem) }\end{array}$} & A. The song of the pirate. ${ }^{1}$ \\
\hline & & B. The sailor and his sailing boat. \\
\hline & & C. The sea and the grouper. \\
\hline & & D. I do not know. \\
\hline & \multirow{4}{*}{$\begin{array}{l}\text { Q6. What animal has an odd } \\
\text { number of arms but not calyx? }\end{array}$} & A. An octopus. \\
\hline & & B. A sea star. ${ }^{1}$ \\
\hline & & C. A sea lily. \\
\hline & & D. I do not know. \\
\hline
\end{tabular}

Q indicates a question. A-D are the potential answers the players can choose between. ${ }^{1}$ The correct answer for each question is highlighted in bold style font.

Data was collected from the five questions Q1-Q5 on pre- and post- test, and results were coded and tabulated. Q6 was not included in the final study tests because no differences were found between tests on both pilot studies. Researchers found through their participant observation that Q6 did not provide any information, and answers were the same before and after the game. Responses to the tests (Q1-Q5) were classified into three groups: 'success' to cluster all correct answers, 'wrong' to group all wrong responses, and 'unaware' that represent all the 'I do not know' answers.

Descriptive analysis, percentages, frequencies, and statistical analyses were calculated with IBM SPSS Statistics programs to obtain a more complete understanding of this [73], and check whether the patterns we observed were mathematically supported. The nonparametric test 'Pearson chi-square of independence' was considered the most appropriate 
to analyse frequencies from two independent samples [74]. This statistical test was used to determine whether the number of correct, and unaware answers differed between the preand post-tests. The analysis was first done on adults and children separately and then in adults and children combined. We used a significance threshold of $p<0.05$.

Finally, the triangulation of the qualitative and quantitative methods employed was done. This research strategy provides an increment of the validity of data collected and could give a relevant interpretation of the information available [75].

\section{Results}

The game was played in 12 sessions, 6 sessions for each group. Every game session lasted approximately between an hour and an hour and a half. During gameplay sessions players, both age groups showed motivation, engagement, and enjoyment during and after the game.

\subsection{Qualitative Information}

\subsubsection{Learning Objectives of the Game}

From observations made as moderators, we verified that all the questions and contents associated with each learning objective were addressed in each game session. Table 4 shows how the questions in the game related to the learning objectives, and classifies them according to the observed level of difficulty encountered by the players during the game sessions. Below, a description of how both samples (i.e., children and adults) performed during the game in terms of different learning objectives.

Table 4. How questions in the game related to learning objectives.

\begin{tabular}{|c|c|c|}
\hline \multirow{2}{*}{$\begin{array}{l}\text { Learning } \\
\text { Objective }\end{array}$} & \multicolumn{2}{|c|}{ Difficulty Level of Question } \\
\hline & Low & High \\
\hline $\begin{array}{l}\text { (a) To recognise organisms from } \\
\text { marine environments. }\end{array}$ & $\begin{array}{l}\text { QA1. Sea sponges are: } \\
\text { A. Animals. }{ }^{1} \\
\text { B. Algae. } \\
\text { C. Plants. }\end{array}$ & $\begin{array}{l}\text { QA2. What group does the seahorse belong } \\
\text { to? Participants should choose one of the } \\
\text { following options: } \\
\text { A. Fish. } 1 \\
\text { B. Shellfish. } \\
\text { C. Jellyfish. }\end{array}$ \\
\hline
\end{tabular}

QB2. The scorpion fish (Trachinus draco) is an invasive species in the Asturian marine

(b) To identify invasive marine species and their environmental consequences.

QB1. In Asturias, only animals are invasive species:

A. True.

B. False. ${ }^{1}$

environment, but it is very similar to the red scorpion fish (Scorpaena scrofa), a native species. Would you be able to identify both of them in these pictures?

Moderators provide two pictures, one of each fish species and team members should discuss to correctly identify each one.

QC2. Are there mountain ranges in the

QC1. In the Picos de Europa National Park you can easily find remains of marine living beings:
A. True.
B. False.

depths of the ocean? Participants should choose one of the following options:

$$
\begin{aligned}
& \text { A. Yes. }{ }^{1} \\
& \text { B. No. }
\end{aligned}
$$


Table 4. Cont.

QD1. How can you make a coin fall into a bottle if it is balanced on a thin stick over the opening? You cannot touch the coin or the stick.

A. Dropping water on the coin. ${ }^{1}$

$$
\text { B. Blowing the coin. }
$$

(d) To apply laws of Mathematics, Physics, and Chemistry to understanding the marine environment.
C. Waiting for an earthquake which would shake the bottle, the coin, and the stick. Moderators provide all materials and instructions needed to participants in order to they carried out on their own the scientific experience successfully and checked the correct answer.
QD2. If we put a candle in the centre of a plate with water, and then we cover it with a glass, what will happen?

A. The water will be drawn into the glass. ${ }^{1}$

B. The candle will melt totally. C. The glass will burst.

Moderators provided all materials and instructions needed to players so that they could carry out the scientific experiment successfully and then checked they got the correct answer. (e) To understand how information about the marine environment that they learnt in schools applies to their daily life.
QE1. The tides are due to:

A. The movement of the rest of the planets.

B. The attraction between the Earth and the Moon. ${ }^{1}$

C. The energy sent by the Sun.

QE2. It is 8 a.m. and in Avilés there is a high tide. According to the forecast, at 20:15 there will be a high tide again. At what time will there be a low tide?
A. At 13:50. 1
B. At 16:10.
C. At $18: 30$.

QF2. The following piece of Espronceda's poem, 'The pirates' song', has lost some

QF1. Which legendary creature does the giant squid correspond to?
A. Moby Dick
B. Kraken. ${ }^{1}$
C. Flipper.

words. Can you fill in the gaps in less than $20 \mathrm{~s}$ ?

Moderators provided a piece of paper where the poem was presented with six blank gaps and a short list of words. Players had to choose the correct words from the list and fill in the gaps.
QG1. Oceans cover:

(g) To discuss and compare information about each topic involved in the game.
A. A half $(1 / 2)$ of the surface of the Earth.

B. A quarter $(1 / 4)$ of the surface of the Earth. C. Two thirds $(2 / 3)$ of the surface of the Earth. ${ }^{1}$
QH1. Each member of the team has to make a paper boat with a piece of newspaper. creative works focused on the marine environment. (h) To produce a wide variety of
Moderators provide some pieces of newspapers to

the team which has less than a minute to complete their creations.
QG2. There are millions of tons of plastic and other rubbish which floats in the oceans. Can this carry invasive species to new locations?

$$
\text { A. True. }{ }^{1}
$$$$
\text { B. False. }
$$

QH2. All the members of the team together act out a topic written on the card and the other teams guess what the topic is. The performing team only scores if the $f$ other team guesses their topic correctly, other teams score by guessing the correct topic. Moderators provide some pieces of papers with topics on, the performing team chooses one without looking at the topics. Topics could include Asturian traditions about whale hunting, the birth of the seahorse, and so on.

${ }^{1}$ The correct answer is highlighted in bold style font.

(a) To recognise organisms from marine ecosystems

Marine organisms were fascinating to most people playing the game, regardless of their age, although knowledge and understanding of these organisms varied considerably. For instance, sea sponges were easily identified as animals (Table 4; QA1) by both samples, whereas some players did not know which groups cetaceans, or seahorses, belonged to (Table 3, Q2; Table 4; QA2). This is despite sea sponges, cetaceans, and seahorses- all being common in the Asturian marine ecosystems. Children could explain to each other that cetaceans were mammals; however, the fact that seahorses were fish needed clarification from the moderator.

(b) To identify invasive marine species and their environmental consequences 
There are plenty of invasive species in the Asturian region, thus we expected players to be aware of them. Players were aware that invasive species could be both plants and animals (Table 4, QB1). However, differentiating between a common non-invasive edible fish (Scorpaena scrofa) and an invasive non-edible one (Trachinus draco) was almost impossible for children. This was less difficult for adults (Table 4, QB2). In the children sample, group teachers and/or moderators provided explanations about the differences between both species. Within the adult sample, some people were able to identify the non-invasive species because they had seen it at the fishmongers. In fact, in one of the adults' game sessions, a retired fishmonger explained the characteristics of both species to the other players.

(c) To relate geological concepts to marine phenomena

Participants of all ages knew about the Cantabrian range, where Picos de Europa National Park is located, in Asturias. Most of the players were aware of the existence of marine fossils in these mountains (Table 4, QC1). However, only a few were able to link this sort of land formation with ocean ridges despite this being part of the school curricula (Table 4, QC2).

(d) To apply laws of Mathematics, Physics, and Chemistry to understanding the marine environment

Questions based on this learning objective were the most demanding for players in both samples. Of these, those the players found hardest were theoretical questions (e.g., Table 3, Q3) and some questions that involved scientific experiments (Table 4, QD2). Children did better than adults in some questions involving scientific experiments (Table 3 , Q3; Table 4, QD1). Providing clear and accurate explanations, for these questions, for their peers was as challenging for children as it was for adults. So, moderators often needed to do this. In all cases, players were pleased to take part in experiments, under supervision, and were delighted with the results observed.

(e) To understand how information about the marine environment that they learnt in schools applies to their daily life

Players understanding of marine phenomena observed in daily life was sometimes less than expected. For example, both children and adults showed poor understanding of what causes tides (Table 4, QE1). Further, only one adult group (that contained a seaman) was able to calculate the timing of the tides (Table 4, QE2). This was despite that there are two high and two low tides and a difference of approximately six hours between a high and low tide is taught at the first level of High School.

(f) To analyse literary works related to marine environments

Players from both samples remembered a literary work featured in this game called 'The pirates' song', from their elementary education (Table 4, QF2). Despite experiencing positive emotions upon remembering this song, players still found it difficult to identify the name of the author and the title of the poem, and also to fill in gaps in its paragraphs. Players found information from more recent literary works easier to recall.

(g) To discuss and compare information about each topic involved in the game

Climate change and how this affects the Earth, in particular the oceans, was discussed by both children and adults. The question relating to how much of the surface of the Earth is covered by oceans was answered successfully in almost all cases (Table 4, QG1). This led several players to comment on the risks of ice melting and the subsequent rise in sea levels. Furthermore, both groups entered into discussions about invasive marine species. However, nobody was able to identify floating rubbish, or the use of vehicles (such us merchant ships), as vectors by which invasive species could enter the marine ecosystem (Table 4, QG2).

(h) To produce a wide variety of creative works focused on the marine environment 
Team creativity was not evident in some groups (Table 4, QH2). We found that adults (especially women in their seventies) tended to be more creative and got more involved in creative activities than children. Nevertheless, all players enjoyed using pieces of newspaper to make boats, for instance. Although some children did not know how to do this, they were taught how by their peers.

\subsubsection{Collaborative Learning}

Players communicated successfully with their peers, which led them acquiring knowledge from the game.

Initially, children were more likely to interact when there was a moderator present. However, as the session progressed peer interaction within the teams increased. This may have been due to the reward of extra points when team members could provide a correct answer to the question.

Adults performed somewhat differently to children. This is possibly due to their different academic and occupational backgrounds. A high level of peer interactions, both within and across the adult teams, was observed. In this case, moderators were only required to clarify concepts, keep the game moving along, or provide materials needed to solve questions.

\subsection{Game Assessment Tool}

Data collected from pre- and post-test is presented in Table 5. How the number of 'correct', 'unaware' and 'wrong' answers changed between the pre- and post-tests is analysed in the next section.

Table 5. Absolute frequencies of correct, wrong and unaware answers for the questions used in our game assessment test.

\begin{tabular}{|c|c|c|c|c|c|c|c|c|}
\hline & & & \multicolumn{2}{|c|}{ Children } & \multicolumn{2}{|c|}{ Adults } & \multicolumn{2}{|c|}{ Total } \\
\hline & & & Pre-Test & Post-Test & Pre-Test & Post-Test & Pre-Test & Post-Test \\
\hline \multirow{6}{*}{ Biology } & \multirow{3}{*}{ Q1 } & Correct & 28 & 99 & 87 & 110 & 115 & 209 \\
\hline & & Wrong & 28 & 7 & 14 & 1 & 42 & 8 \\
\hline & & Unaware & 55 & 5 & 10 & 0 & 65 & 5 \\
\hline & \multirow{3}{*}{ Q2 } & Correct & 23 & 85 & 61 & 90 & 84 & 175 \\
\hline & & Wrong & 63 & 24 & 43 & 20 & 106 & 44 \\
\hline & & Unaware & 25 & 2 & 7 & 1 & 32 & 3 \\
\hline \multirow{6}{*}{ Physics } & \multirow{3}{*}{ Q3 } & Correct & 10 & 107 & 38 & 105 & 48 & 212 \\
\hline & & Wrong & 96 & 4 & 68 & 6 & 164 & 10 \\
\hline & & Unaware & 5 & 0 & 5 & 0 & 10 & 0 \\
\hline & \multirow{3}{*}{ Q4 } & Correct & 93 & 107 & 63 & 107 & 156 & 214 \\
\hline & & Wrong & 17 & 1 & 40 & 4 & 57 & 5 \\
\hline & & Unaware & 1 & 3 & 8 & 0 & 9 & 3 \\
\hline \multirow{3}{*}{ Literature } & \multirow{3}{*}{ Q5 } & Correct & 36 & 72 & 88 & 103 & 124 & 175 \\
\hline & & Wrong & 56 & 34 & 12 & 8 & 68 & 42 \\
\hline & & Unaware & 19 & 5 & 11 & 0 & 30 & 5 \\
\hline
\end{tabular}

\subsubsection{Analyses of Correct Answers}

Children only had one question in the pre-test (Q4), in which they had a frequency of correct answers higher than 50\% (93 correct answers mean 83.78\%; Table 4). In adults, the frequency of correct answers in the pre-test was higher than $50 \%$ for all questions, apart from Q3 (for which the frequency of correct answers was 38, it means 34.23\%; Table 4).

In both age groups, the post-test mean frequency of correct answers was significantly higher than the pre-test mean frequency of correct answers (Table 6). Standard deviation was lower in the pre-test than in the post-test, for both samples, and, in both tests adults had more homogenous answers than children (Table 6). 
Table 6. Descriptive statistics for frequency of correct answers in the pre-tests and post-tests.

\begin{tabular}{ccccccc}
\hline & \multicolumn{2}{c}{ Children } & \multicolumn{2}{c}{ Adults } & \multicolumn{2}{c}{ Total } \\
\hline Test & Mean & SD & Mean & SD & Mean & SD \\
\hline Pre-test & 59.78 & 33.10 & 72.54 & 17.11 & 67.94 & 24.87 \\
Post-test & 95.97 & 12.94 & 103.46 & 6.63 & 99.89 & 10.81 \\
\hline
\end{tabular}

Significant differences between pre-test and post-test in each subsample and within each question were detected. Children differences between pre-test and post-test were highly significant (Chi-square $=60.848, p$-value $=0.000$ ). Correct answers increased from less than $30 \%$ in the pre-test, to over $70 \%$ in the post-test (Table 7 ). In adults, Chisquare also yields significant differences between pre-test and post-test correct answers. $($ Chi-square $=15.711, p$-value $=0.003)$. The increment between the pre- and post-test was from $39.6 \%$ to $60.4 \%$ (Table 7 ).

Table 7. Correct answers cross table: percentage (\%) of correct answers within each question and whole tests.

\begin{tabular}{cccccccccccccc}
\hline & \multicolumn{2}{c}{ Q1 } & \multicolumn{2}{c}{ Q2 } & \multicolumn{2}{c}{ Q3 } & \multicolumn{2}{c}{ Q4 } & \multicolumn{2}{c}{ Q5 } & \multicolumn{2}{c}{ Total } \\
\hline Test & CH & AD & CH & AD & CH & AD & CH & AD & CH & AD & CH & AD \\
\hline Pre-test & 22.0 & 44.2 & 21.3 & 40.4 & 8.5 & 26.6 & 46.5 & 37.1 & 33.3 & 46.1 & 28.8 & 39.6 \\
Post-test & 78.0 & 55.8 & 78.7 & 59.6 & 91.5 & 73.4 & 53.5 & 62.9 & 66.7 & 53.9 & 71.2 & 60.4 \\
\hline
\end{tabular}

$\mathrm{CH}$ : children; AD: adults.

The question on which both age groups achieved the highest scores in the post-test (and the highest increase in scores between pre- and post-tests) was Q3 (Table 7). There were also significant differences in the frequency of correct answers between the pre-tests and post-tests, for both age groups, for Q1 (Chi-square $=16.495, p$-value $=0.000), \mathrm{Q} 2$ $($ Chi-square $=10.483, p$-value $=0.001), \mathrm{Q} 3($ Chi-square $=13.891, p$-value $=0.000)$ and Q5 $($ Chi-square $=4.613, p$-value $=0.032)$ but not for Q4 $($ Chi-square $=3.359, p$-value $=0.067)$.

\subsubsection{Analyses of Unaware Answers}

The frequency of unaware answers was significantly lower than the frequency of correct answers in general. Descriptive statistics (Table 8) show that unaware answers were more frequent in pre-test than in post-test and this pattern was more pronounced in children than in adults. First, children were more likely to give an unaware answer for each question compared to adults (Table 8). Second, children had a larger decrease in the number of unaware answers between pre- and post-tests than adults, this decrease was significant for children $($ Chi-square $=18.116, p$-value $=0.001)$, but not for adults $($ Chi-square $=4.354$, $p$-value $=0.360$ )

Table 8. Unaware answers descriptive statistics in each test and subsample.

\begin{tabular}{ccccccc}
\hline & \multicolumn{2}{c}{ Children } & \multicolumn{2}{c}{ Adults } & \multicolumn{2}{c}{ Total } \\
\hline Test & Mean & SD & Mean & SD & Mean & SD \\
\hline Pre-test & 38.45 & 18.02 & 8.76 & 2.05 & 30.11 & 20.33 \\
Post-test & 4.21 & 1.2 & 1.00 & - & 4.00 & 1.41 \\
\hline
\end{tabular}

Q1 and Q5 were the questions which both age groups were most likely to give an unaware answer to (Table 4). For Q4, the number of unaware answers increased between the pre- and post-tests, from one unaware answer in the pre-test to three unaware answers in the post-test (Table 4).

Overall, considering both samples together unaware answers decreased sharply between the pre- and post-tests (Table 9). However, there were significant differences in the 
frequency of unaware answers between the pre-tests and post-tests, for both age groups, only for Q4 (Chi-square $=8.000, p$-value $=0.005)$, but not for Q1 (Chi-square $=0.897$, $p$-value $=0.343), \mathrm{Q} 2($ Chi-square $=0.204, p$-value $=0.651)$, and Q5 $($ Chi-square $=2.674$, $p$-value $=0.102)$.

Table 9. 'Unaware' answers cross table: percentage (\%) of correct responses within each question and whole tests.

\begin{tabular}{cccccccccccccc}
\hline & \multicolumn{2}{c}{ Q1 } & \multicolumn{2}{c}{ Q2 } & \multicolumn{2}{c}{ Q3 } & \multicolumn{2}{c}{ Q4 } & \multicolumn{2}{c}{ Q5 } & \multicolumn{2}{c}{ Total } \\
\hline Test & CH1 & AD & CH & AD & CH & AD & CH & AD & CH & AD & CH & AD \\
\hline Pre-test & 91.7 & 100.0 & 92.6 & 87.5 & 100.0 & 100.0 & 25.0 & 100.0 & 79.2 & 100.0 & 87.5 & 97.6 \\
Post-test & 8.3 & 0.0 & 7.4 & 12.5 & 0.0 & 0.0 & 75.0 & 0.0 & 20.8 & 0.0 & 12.5 & 2.4 \\
\hline
\end{tabular}

CH: children; AD: adults.

\subsubsection{Analyses Considering Each Topic Separately}

Knowledge increase occurred in all the three topics covered by the test (Figure 2). Children's knowledge increased substantially in Biology and Physics, and they show considerably higher scores in the post-test, compared to the pre-test, in the literature. Adults showed a high and similar post-test percentage of correct answers regarding Physics questions compared to the children.

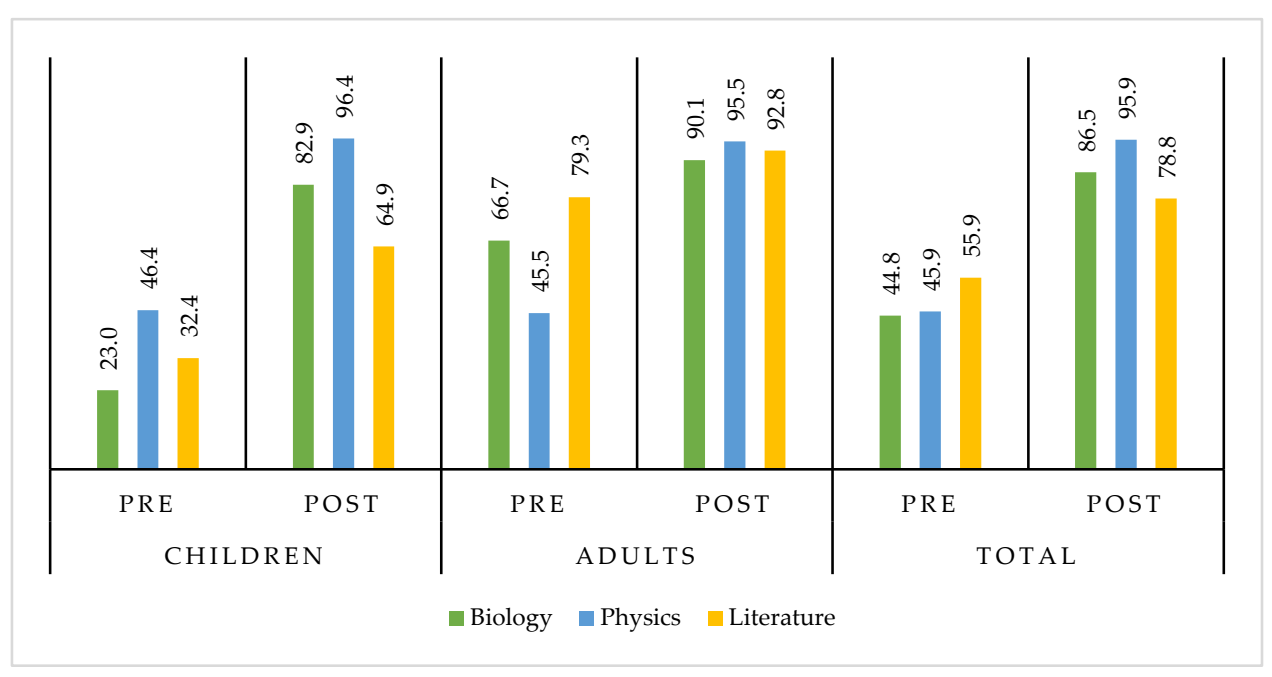

Figure 2. Knowledge (\%) in the three main topics of 'The Game of the Sea': Biology, Physics, and Literature, comparing pre- and post- tests data of both studied samples (children and adults).

Unaware answers decreased in each age group and in each topic (Figure 3). The sharpest decrease in unaware answers, particularly in children, was in Biology. There was also a decrease in the number of unaware answers in terms of Literature questions. More adults gave unaware answers to Physics question in the pre-test compared to children, but were less likely to do so, compared to children, in the post-test. Overall, adults were less likely than children to give an unaware response in the whole post-test. 


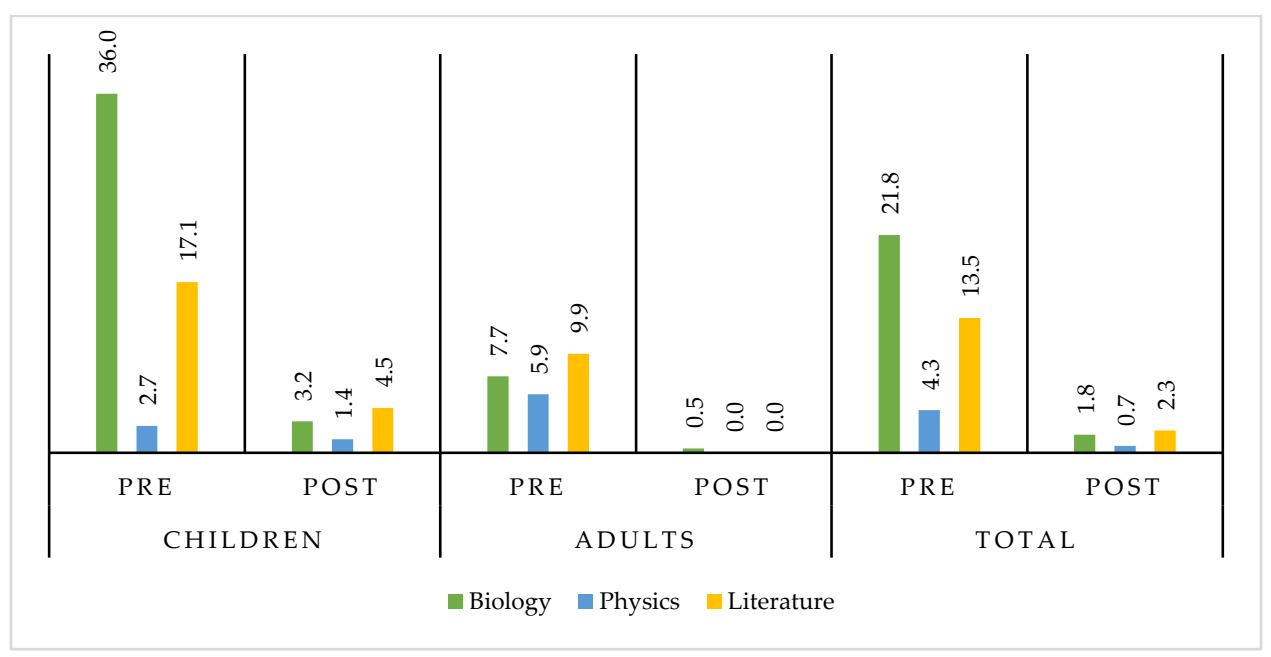

Figure 3. 'Unaware' percentage (\%) in biology, physics), and literature in each subsample (children and adults), before and after playing 'The Game of the Sea'.

\section{Discussion and Conclusions}

'The Game of the Sea' gave players the opportunity to acquire knowledge on a wide range of topics related to the marine environment. Sometimes scientific communication is not clear and/or not accessible enough to citizens [76]. Board games can, therefore, play an important role in scientific communication by simplifying complex scientific concepts, or environmental issues, to make the salient points understandable to citizens $[8,33,37,58]$. As well as being educational, some of the cards used in our game appeared to be thoughtprovoking [77], creating much discussion among players, who were regularly surprised by their contents, and inspiring them to find out more about specific topics. Two of the most discussed topics were marine invasive species and the sea level rise.

Previous studies suggest that game-based learning (GBL) engages participants and significantly increases knowledge [18,78,79]. 'The Game of the Sea' supports these findings, further demonstrating that board games, and GBL in general, can be important in educational contexts. Game elements which were specifically designed for 'The Game of the Sea' (such as an overly sized die, seashells as playing pieces, or sticker points) made the game more enjoyable for players. This, in turn, made players more self-confident while playing [53], which contributed to them achieving the learning objectives of the game [52]. Different participants played the game with different attitudes, which often changed over the course of the game. At the start of the game, players often showed high levels of competitiveness towards each other, in each sample. It decreased as the game progressed and players increasingly worked together to find the right solutions. This working together attitude produced collaborative learning which certainly contributed to the game success in improving players' knowledge about marine ecosystems [35], and showed that this game could be an efficient didactic tool for both children and adults [80,81]. As well as fostering collaborative learning, the discussions and interactions that took place in the game, generated by the game cards fostered other important skills, such as critical thinking, scientific reasoning, decision making, problem solving, collaboration, and creativity.

As well as being a tool for teaching about the marine environment, "The Game of The Sea' has other positives attributes. First, all the materials for the game are accessible on request, can be handmade, and can be replicated at a low cost (less than EUR 20). This makes 'The Game of the Sea' an easy to replicate and affordable, didactic tool, available to different educational levels and situations. Second, the cards used in this game are very versatile, allowing the contents of the game to be adapted for use in various situations, without modifying the format of the game. This, along with that the game is determined by how players interact, increases its unpredictability, making it more interesting. 
Pre- and post-test questions were used to verify if players achieved the learning objectives of the game. What players got out of the game, in terms of knowledge acquisition, could have been influenced by their age and background (both academic and occupational). Although both age samples showed significant increases in the number of correct answers between pre-test and post-test results, this was more pronounced in children than in adults. A potential explanation for this is that all the information contained in the game cards is taught in official educational programs in Europe. Thus, adults would have finished their education on these topics while children may not have yet. Therefore, this game could be considered as a noteworthy didactic tool (in terms of knowledge acquisition) for an interdisciplinary approach of those scientific contents related to marine environment from the official curricula of Spanish Compulsory Elementary, Middle and High School Education.

Players did not necessarily find different questions on the same topics to be of similar difficulty. For example, children found Q4 (If we have two balloons, one with air and the other one with some water, and we heat them, which one will blow out first? R4: The balloon only with air) the easiest to answer in the pre-test, and adults found Q3 (Where does the speed of a sound go faster? R3: In the water) the hardest, despite both questions being Physics questions. One explanation for why players were much more likely to know the answer to Q4 than Q3 is that Q4 is more easily tested with an experiment than Q3. There was little increase in the number of correct answers in Q4 between pre- and post-tests (most players got it right both times), which suggests that players may have already seen this experiment, or a similar one, prior to playing the game. When children and adults were considered together, Q3 showed the greatest increase in the number of correct answers between pre- and post-test. Peer interaction contributed to this, Q3 was, overall, one of the most clarified questions. In general, the discussions which took place during gameplay among players and with moderators, allowed for clarification of misconceptions, thus enabling players to successfully reach the learning objectives of the game [39].

Through playing 'The Game of the Sea' players improved their interdisciplinary knowledge on the marine environment and critical situations facing this environment. Thus, the game achieved its 3 main goals: (1) To enable students to achieve learning objectives (based on the official curricula of Spanish Compulsory High School Education) in terms of learning about the marine environment. (2) To foster collaborative learning, regardless of age or educational background. (3) To raise awareness about critical situations regarding our marine environment, and the need to preserve this environment. Achieving this third goal was especially important. Nowadays, policies to protect the marine ecosystems are not well enforced/often overlooked [82], and politicians and lawmakers appear to have little concern for the marine environment. Thus, marine ecosystems increasingly rely on the general public to help protect and preserve them. Consequently, raising public awareness of the situations our marine environments face (e.g., through board games, which can simultaneously educate and entertain people from many walks of life [63]) can positively contribute to achieving marine conservation objectives [83,84]. In this study 'The Game of the Sea', was shown to facilitate learning [13] about the marine ecosystems, thus enhancing awareness, in all ages, of the importance of preserving this environment.

\section{Patents}

'The Game of the Sea' has been registered at Intellectual Property Registry of the Principality of Asturias in Spain with the copyright reference 05/2017/329.

Author Contributions: Conceptualization, E.A.-G. and L.M.; methodology, E.A.-G. and L.M.; validation, E.A.-G. and L.M.; formal analysis, E.A.-G.; investigation, E.A.-G.; resources, E.A.-G.; data curation, E.A.-G.; writing-original draft preparation, E.A.-G.; writing-review and editing, E.A.-G. and L.M.; supervision, L.M. All authors have read and agreed to the published version of the manuscript.

Funding: This research received no external funding. 
Institutional Review Board Statement: The study was conducted according to the guidelines of the Declaration of Helsinki. The protocol was approved by the high schools IES Escultor Juan de Villanueva and IES Salinas, and the University of Oviedo where the research took place.

Informed Consent Statement: Informed consent was obtained from all subjects involved in the study.

Data Availability Statement: The data presented in this study are available on request from the corresponding author.

Acknowledgments: The authors acknowledge 'Surf, Music \& Friends Festival' and the surf school 'El Pez Escorpión', in Salinas (Asturias, Spain) the opportunity to play and test the game as a pilot study therein. It was also played in ALERTOOLS International Workshop. We have collected data thanks to the interest in the game of teachers and students from IES Escultor Juan de Villanueva and IES Salinas; students from Elementary Teaching Degree, High School Teaching Master of the University of Oviedo, and participants in Evolution Club of University of Oviedo. This research is part of Elena Arboleya García thesis from PhD Programme in Education and Psychology. Laura Miralles holds a Torres Quevedo grant from the Government of Spain (PTQ2018-010019).

Conflicts of Interest: The authors declare no conflict of interest.

\section{References}

1. Huizinga, J. Homo Ludens, 6th ed.; Alianza Editorial: Madrid, Spain, 2007.

2. Caillois, R. Man, Play and Games; University of Illinois Press: Champaign, IL, USA, 2001.

3. Allery, L.A. Educational games and structured experiences. Med. Teach. 2004, 26, 504-505. [CrossRef]

4. Backlund, P.; Hendrix, M. Educational games-are they worth the effort? A literature survey of the effectiveness of serious games. In Proceedings of the 2013 5th International Conference on Games and Virtual Worlds for Serious Applications (VS-GAMES), Poole, UK, 11-13 September 2013.

5. Connolly, T.M.; Boyle, E.A.; MacArthur, E.; Hainey, T.; Boyle, J.M. A systematic literature review of empirical evidence on computer games and serious games. Comput. Educ. 2012, 59, 661-686. [CrossRef]

6. Qian, M.; Clark, K.R. Game-based Learning and 21st century skills: A review of recent research. Comput. Hum. Behav. 2016, 63, 50-58. [CrossRef]

7. Abt, C.C. Serious Games; University Press of America: Lanham, MD, USA, 1987.

8. Al-Azawi, R.; Al-Faliti, F.; Al-Blushi, M. Educational gamification vs. Game based learning: Comparative study. Int. J. Innov. Manag. Technol. 2016, 7, 132-136. [CrossRef]

9. Djaouti, D.; Álvarez, J.; Jessel, J.P. Classifying serious games: The G/P/S model. In Handbook of Research on Improving Learning and Motivation through Educational Games: Multidisciplinary Approaches; Felicia, P., Ed.; IGI Global: Hershey, Pennsylvania, USA, 2011; pp. 118-136. [CrossRef]

10. Aranda Juárez, D.; Gómez García, S.; Navarro Remesal, V.; Planells de la Maza, A.J. Game E Play: Diseño y Análisis del Juego, el Jugador y el Sistema Lúdico; UOC Press-Comunication: Barcelona, Spain, 2015.

11. Khan, A.; Pearce, G. A study into the effects of a board game on flow in undergraduate business students. Int. J. Manag. Educ. 2015, 13, 193-201. [CrossRef]

12. Anneta, L.A. The "I's" have it: A framework for serious educational game design. Rev. Gen. Psychol. 2010, 14, 105-112. [CrossRef]

13. Subhash, S.; Cudney, E.A. Gamified learning in higher education: A systemic review of the literature. Comput. Hum. Behav. 2018, 87, 192-206. [CrossRef]

14. De Freitas, S. Learning in Immersive Worlds: A Review of Game-Gased Learnging; Published Version Deposited in CURVE September 2013 Original; Joint Information Systems Committee: Bristol, UK, 2013.

15. Cheng, P.H.; Yeh, T.K.; Chao, Y.K.; Lin, J.; Chang, C.Y. Design ideas for an issue-situation-based board game involving multirole scenarios. Sustainability 2020, 12, 2139. [CrossRef]

16. Piñero Charlo, J.C. Análisis sistemático del uso de salas de escape educativas: Estado del arte y perspectivas de future. Espacios 2019, 40, 9 .

17. Bai, S.; Foon, K.; Huang, B. Does gamification improve student learning outcome? Evidence from a meta-analysis and synthesis of qualitative data in educational contexts. Educ. Res. Rev. 2020, 30, 100322. [CrossRef]

18. Cardinot, A.; Fairfield, J.A. Game-based learning to engage students with physics and astronomy using a board game. IJGBL 2019, 9, 42-57. [CrossRef]

19. Talan, T.; Doğan, Y.; Batdı, V. Efficiency of digital and non-digital educational games: A comparative meta-analysis and a metathematic analysis. J. Res. Technol. Educ. 2020, 52, 474-514. [CrossRef]

20. Franklin, S.; Peat, M.; Lewis, A. Non-traditional interventions to stimulate discussion: The use of games and puzzles. J. Biol. Educ. 2003, 37, 79-84. [CrossRef]

21. Boghian, I.; Cojocariu, V.M.; Popescu, C.V.; Mâță, L. Gambe-based learning. Using board games in adult education. J. Educ. Sci. Psychol. 2019, 9, 51-57. 
22. Hakak, S.; Noor, N.F.M.; Ayub, M.N.; Affal, H.; Hussin, N.; Ahmed, E.; Imran, M. Cloud-assisted gamification for education and learning-Recent advances and challenges. Comput. Electr. Eng. 2019, 74, 22-34. [CrossRef]

23. Lester, J.C.; Spires, H.A.; Nietfeld, J.L.; Minogue, J.; Mott, B.W.; Lobene, E.V. Designing game-based learning environments for elementary science education: A narrative-centered learning perspective. Inf. Sci. 2014, 264, 4-18. [CrossRef]

24. Antunes, M.; Pacheco, M.A.R.; Giovanela, M. Design and implementation of an educational game for teaching chemistry in higher education. J. Chem. Educ. 2012, 89, 517-521. [CrossRef]

25. García-Molina, R. Ciencia recreativa: Un recurso didáctico para enseñar deleitando. Rev. Eureka Sobre Enseñanza Y Divulg. De Las Cienc. 2011, 8, 370-392. [CrossRef]

26. Sardone, N.B.; Devlin-Scherer, R. Let (board) games begin: Creative ways to enhance teaching and learning. Clear. House 2016, 89, 215-222. [CrossRef]

27. Kober, S.E.; Wood, G.; Kiili, K.; Moeller, K.; Ninaus, M. Game-based learning environments affect frontal brain activity. PLoS ONE 2020, 15, e0242573. [CrossRef]

28. Avdiu, E. Game-Based Learning Practices in Austrian Elementary Schools. Educ. Process Int. J. 2019, 8, 196-206. [CrossRef]

29. Higueras-Rodríguez, L.; Medina-García, M.; Molina-Ruiz, E. Analysis of courses and teacher training programs on playful methodology in Andalusia (Spain). Educ. Sci. 2020, 10, 105. [CrossRef]

30. Lickiewicz, J.; Paulsen Hughes, P.; Makara-Studzińska, M. The use of board games in healthcare teaching. Nurs. Probl. 2020, 28, 71-74. [CrossRef]

31. Taspinar, B.; Schmidt, W.; Schuhbauer, H. Gamification in education: A board game approach to knowledge acquisition. Procedia Comput. Sci. 2016, 99, 101-116. [CrossRef]

32. D'Astous, A.; Gagnon, K. An inquiry into the factors that impact on consumer appreciation of a board game. J. Consum. Mark. 2007, 24, 80-89. [CrossRef]

33. Liomas, I.; Altanis, I.; Retails, S. An authoring toolkit for creating digital learning board games for cognitive and social skills development. In Proceedings of the 2017 IEEE Global Engineering Education Conference (EDUCON), Athens, Greece, 25-28 April 2017; pp. 508-513.

34. Chiarello, F.; Castellano, M.G. Board games and board game design as learning tool for complex scientific concepts: Some experiences. IJGBL 2016, 6, 1-14. [CrossRef]

35. Tsai, J.C.; Cheng, P.H.; Liu, S.Y.; Chang, C.Y. Using board games to teach socioscientific issues on biological conservation and economic development in Taiwan. J. Baltic Sci. Educ. 2019, 18, 634-645. [CrossRef]

36. Tasmin, R.; Yahya, S. "Old fashioned, yet admirable". Revisiting Bloom to revolutionize board gaming in our entrepreneurship classrooms. ACRN J. Entrep. Perspect. 2014, 3, 31-42.

37. Bayeck, R.Y. Examining board gameplay and learning: A multidisciplinary review of recent research. Simul. Gaming 2020, 51, 411-431. [CrossRef]

38. William, L.; Rahim, Z.A.B.A.; De Souza, R.; Nugroho, E.; Fredericco, R. Extendable board game to facilitate learning in supply chain management. ASTESJ 2018, 3, 99-111. [CrossRef]

39. Siwela, M. Making serious learning easy and fun at OHFT: Educational board games. Libr. Inf. Res. 2020, 43. [CrossRef]

40. Matera, M. Explora Como un Pirata; Mensajero: Bilbao, Spain, 2018.

41. Gonzalo-Iglesia, J.L.; Lozano-Monterrubio, N.; Prades-Tena, J. Noneducational board games in University Education. Perceptions of students experiencing game-based learning methodologies. Rev. Lusófona De Educ. 2018, 41, 45-62. [CrossRef]

42. Miralles, L.; Morán, P.; Dopico, E.; García-Vázquez, E. DNA Re-EvolutioN: A game for teaching learning molecular genetics and evolution. Biochem. Mol. Biol. Educ. 2013, 41, 396-401. [CrossRef]

43. Parrondo, M.; Rayón-Viña, F.; Borrel, Y.J.; Miralles, L. Sustainable Sea: A board game for engaging students in sustainable fisheries management. Appl. Environ. Educ. Commun. 2021, 20, 406-421. [CrossRef]

44. Muell, M.R.; Guillory, W.X.; Kellerman, A.; Rubio, A.O.; Scott-Elliston, A.; Morales, O.; Eckhoff, K.; Barfknecht, D.; Hartsock, J.A.; Weber, J.J. Gaming natural selection: Using board games as simulations to teach evolution. Evolution 2020, 74, 681-685. [CrossRef]

45. Juan, Y.K.; Chao, T.W. Game-based learning for green building education. Sustainability 2015, 7, 5592-5608. [CrossRef]

46. Tanel, R.; Önder, E.B. Developing and testing a board game to learn about stars. IJGBL 2020, 10, 62-73. [CrossRef]

47. Queiroz de Cavalho, J.C.; Beltramini, L.M.; Segnini Bossolan, N.R. Using a board game to teach protein synthesis to high school students. J. Biol. Educ. 2018, 53, 205-216. [CrossRef]

48. West, S. A bird-based game takes wing. Nature 2019, 569, 334-335. [CrossRef]

49. Steinberger, F.; Minder, T.; Trutnevyte, E. Efficiency versus Equity in Spatial Siting of Electricity Generation: Citizen Preferences in a Serious Board Game in Switzerland. Energies 2020, 13, 4961. [CrossRef]

50. Cheng, P.H.; Yeh, T.K.; Chao, Y.K.; Lin, J.; Chang, C.Y. Development of an issue-situation-based board game: A systematic learning evironment for wáter resourde adpatation education. Sustainability 2019, 11, 1341. [CrossRef]

51. Grechus, M.; Brown, J. Comparison of individualized computer game reinforcement versus peer-interactive board game reinforcement on retention of nutrition label knowledge. J. Health Educ. 2000, 31, 138-142. [CrossRef]

52. Argenton, L.; Muzio, M.; Shek, E.J.; Mantovani, F. Multiplayer serious games and user experience: A comparison between paper-based and digital gaming experience. In Games and Learning Alliance. GALA 2014. Lecture Notes in Computer Science; De Gloria, A., Ed.; Springer: Cham, Switzerland, 2014; pp. 54-62. [CrossRef] 
53. Martindale, R.C.; Weiss, A.M. Taphonomy: Dead and fossilized: A new board game designed to teach college undergraduate students about the process of fossilization. J. Geosci. Educ. 2020, 68, 265-285. [CrossRef]

54. Rose, T.M. A board game to assist Pharmacy students in learning metabolic pathways. Am. J. Pharm. Educ. 2011, 75, 183. [CrossRef] [PubMed]

55. Martín-Lara, M.A.; Calero, M. Playing a board game to learn bioenergy and biofuels topics in an interactive, engaging context. J. Chem. Educ. 2020, 97, 1375-1380. [CrossRef]

56. Calvo, L.F.; Herrero Martínez, R.; Paniagua Bermejo, S. Influencia de procesos de ludificación en entornos de aprendizaje STEM para alumnos de Educación Superior. Trilogía Cienc. Tecnol. Soc. 2020, 12, 35-68. [CrossRef]

57. Ocean Literacy: The Essential Principles and Fundamental Concepts of Ocean Sciences for Learners of All Ages (2020). Available online: https: / / oceanliteracy.unesco.org/resource/ocean-literacy-the-essential-principles-and-fundamental-concepts-of-oceansciences-for-learners-of-all-ages-2020/ (accessed on 1 September 2021).

58. Fjællingsdal, K.S.; Klöckner, C.A. Green across the board: Board games as tools for dialogue and simplified environmental communication. Simul. Gaming 2020, 51, 632-652. [CrossRef]

59. Cudaback, C. Ocean literacy. There's more to it than content. Oceanography 2008, 21, 10-11. [CrossRef]

60. MacNeil, S.; Hoover, C.; Ostertag, J.; Yumagulova, L.; Glithero, L. Coming to termes with ocean literacy. Can. J. Environ. Educ. 2021, 24, 233-252.

61. West, D. Ocean literacy is key to preserving our oceans and coasts. Mar. Technol. Soc. J. 2004, 38, 68-69. [CrossRef]

62. Veronica, R.; Calvano, G. Promoting Sustainable Behavior Using Serious Games: SeAdventure for Ocean Literacy. IEEE Access 2020, 8, 196931-196939. [CrossRef]

63. Worm, B.; Elliff, C.; Fonseca, G.J.; Gell, F.R.; Serra-Gonçalves, C.; Helder, N.K.; Murray, K.; Peckham, H.; Prelovec, L.; Sink, K. Making ocean literacy inclusive and accessible. Ethics Sci. Environ. Politics 2021, 21, 1-9. [CrossRef]

64. Caro Saiz, J.; Díaz-de la Fuente, S.; Ahedo, V.; Zurro Hernández, D.; Madella, M.; Galán, J.M.; Izquierdo, L.R.; Santos, J.I.; del Olmo, R. Terra Incógnita: Libro Blanco Sobre Transdisciplinariedad y Nuevas Formas de Investigación en el Sistema Español de Ciencia y Tecnolog; PressBooks: Madrid, Spain, 2020.

65. Giménez Pardo, C.; Pagés Arévalo, C.; Martínez Herráiz, J.J. Análisis, diseño y desarrollo de un juego educativo para ordenador sobre enfermedades tropicales y salud internacional: Una herramienta docente más de apoyo al profesor. Rev. De Docencia Univ. 2011, 8, 131-146. [CrossRef]

66. Domínguez, A.; Saenz-de-Navarrete, J.; de-Marcos, L.; Fernández-Sanz, L.; Pagés, C.; Martínez-Herráiz, J.J. Gamifying learning experiences: Practical implications and outcomes. Comput. Educ. 2013, 63, 380-392. [CrossRef]

67. Huizenga, J.C.; Ten Dam, G.T.M.; Voogt, J.M.; Admiraal, W.F. Teacher perceptions of the value of game-based learning in secondary education. Comput. Educ. 2017, 110, 105-115. [CrossRef]

68. Bopp, M. Didactic analysis of digital games and game-based learning. In Affective and Emotional Aspects of Human-Computer Interaction, 2nd ed.; Pivec, M., Ed.; IOS Press: Amsterdam, The Netherlands, 2006; Volume 1, pp. 8-37.

69. Hassan, M.M.; Abdullah-Al-Wadud, M.; Almogren, A.; Rahman, S.M.M.; Alelaiwi, A.; Alamri, A.; Hamid, M.A. QoS and trust-aware coalition formation game in data-intensive cloud federations. Concurr. Comput. Pract. Exp. 2016, 28, 2889-2905. [CrossRef]

70. McMillan, J.H.; Schumacher, S. Investigación Educativa, 5th ed.; Pearson Educación: Madrid, Spain, 2005.

71. León, O.G.; Montero, I. Diseño de Investigaciones, 2nd ed.; McGraw Hill: Madrid, Spain, 1997.

72. Rodríguez Gómez, G.; Gil Flores, J.; García Jiménez, E. Metodología de la Investigación Cualitativa; Ediciones Aljive: Málaga Spain, 1996.

73. Guzmán, P. Estadística Elemental Aplicada a la Educación; Editorial Escuela Española: Madrid, Spain, 1960.

74. Welkowitz, J.; Ewen, R.B.; Cohen, J. Estadística Aplicada a las Ciencias de la Educación; Aula XXI/Santillana: Madrid, Spain, 1986.

75. Rodríguez Ruiz, O. La Triangulación Como Estrategia de Investigación en Ciencias Sociales. Rev. Madr. 2005, 31, 2-4.

76. Klöckner, C.A. The Psychology of Pro-Environmental Communication: Beyond Standard Information Strategies, 1st ed.; Palgrave Macmillan: London, UK, 2015.

77. Rebolledo-Mendez, G.; Avramides, K.; De Freitas, S.; Memarzia, K. Societal impact of a serious game on raising public awareness: The case of FloodSim. In Proceedings of the 2009 ACM SIGGRAPH Symposium on Video Games, New Orleans, LA, USA, 4-6 August 2009; pp. 15-22.

78. Buckley, P.; Doyle, E. Gamification and student motivation. Interact. Learn. Environ. 2016, 24, 1162-1175. [CrossRef]

79. Holzmann, S.L.; Schäfer, H.; Groh, G.; Plecher, D.A.; Klinder, G.; Schauberger, G.; Hauner, H.; Holzpfel, C. Short-term effects of the serious game "Fit, food, fun" on nutritional knowledge: A pilot study among children and adolescents. Nutrients 2019, 11, 2031. [CrossRef]

80. Rodríguez Barreiro, L.M.; Escudero Escorza, T. Interacción entre iguales y aprendizaje de conceptos científicos. Enseñanza De Las Cienc. 2000, 18, 255-274. [CrossRef]

81. Meza Arcos, L.; García Vigil, H. El juego como un elemento favorecedor al acercamiento de las ciencias: En particular, en las actividades deficiencia recreativa. In X Reunión de la Red de Popularización de la Ciencia y la Tecnología en América Latina y el Caribe (RED POP-UNESCO) y IV Taller Ciencia; Comunicación y Sociedad: San José, Costa Rica, 2007.

82. McCauley, D.J.; Pinsky, M.L.; Palumbi, S.R.; Estes, J.A.; Joyce, F.H.; Warner, R.R. Marine defaunation: Animal loss in the global ocean. Science 2015, 347, 1255641. [CrossRef] [PubMed] 
83. Jefferson, R.; McKinley, E.; Capstick, S.; Fletcher, S.; Griffin, H.; Milanese, M. Understanding audiences: Making public perceptions research matter to marine conservation. Ocean. Coast. Manag. 2015, 115, 61-70. [CrossRef]

84. Rodela, R.; Ligtenberg, A.; Bosma, R. Conceptualizing Serious Games as a Learning-Based Intervention in the Context of Natural Resources and Environmental Governance. Water 2019, 11, 245. [CrossRef] 